\title{
Investigating the Motives and Barriers Affecting the Participation of Nursing Students in Voluntary Activities in Jeddah, KSA
}

\author{
Ola Mamdouh Esheaba, Lecturer \\ Community Health Nursing, Faculty of Nursing, Alexandria University, Egypt \\ Shahad Nabeel Abudawood, Student \\ College of Nursing, Saud Bin Abdul-Aziz University for Health Sciences, Saudi Arabia \\ Sahar Riyad Faraj, Student \\ College of Nursing, Saud Bin Abdul-Aziz University for Health Sciences, Saudi Arabia \\ Salma Qadi, Student \\ College of Nursing, Saud Bin Abdul-Aziz University for Health Sciences, Saudi Arabia
}

\begin{abstract}
The volunteer work has crucial role in providing and functioning the communities' social services. Nowadays young volunteers are the major component of volunteer population around the world. Literature revealed significant benefits for volunteer activities such as enhancement of academic development and personal skills. However, motives and barriers affect the involvements in voluntary activities. Nursing students provide a unique sample of the young Saudis female in volunteerism. Objective: Investigate the motives and barriers that affect the participation of nursing students in voluntary activities. Setting: The study was conducted at King Saud Bin Abdul-Aziz University for Health Sciences - College of Nursing and College of Basic Sciences, Jeddah, KSA. Subjects: Non-probability convenient sample of 199 students were included. Tools: A questionnaire was developed by the researchers. Results: $52.3 \%$ of the nursing students' participated in voluntary activities, $47.7 \%$ of them were single, and $45.2 \%$ enrolled in stream I. Improved communication skills was the most reported benefit as reported by $25.2 \%$ of senior students compared to $19.3 \%$ of junior students. Health related activities were the common type of activities among the participants. Regarding motives of participation, passion about charity and helping other were reported as the first motive among participants, following by improving personal skills. While time limitations and unaware about ways of participation were reported as priority barriers for non-participation. Conclusion: The study showed number of motives and barriers affecting the involvement of nursing student's participation in voluntary activities. The more we understand the motivations and barriers underlying the volunteering among nursing students, the more informed the strategies that can be used to encourage them to engage in volunteering. Recommendations: All efforts should be collaborated to increase students' awareness about the benefits of volunteering activities, ways of participation and different forms of volunteering activities as well to overcome all the barriers that prevent them to participate in voluntary activities.
\end{abstract}

Keywords: Voluntary activities, Motives, Barriers; Nursing students.

\section{Introduction}

Volunteering activities are common aspects in establishing the society's health. Wilson (2000) defined volunteerism as "any activity, formal or informal, which is conducted by choice in an unpaid manner to benefit another person, group, or organization" $^{(1)}$. While Ehigiegba, Aivinhenyo-Uyi, Fakunle, Fajola and Aguwa (2014) defined it as "the principle of donating the time and energy for the benefit of other people in the community as a social responsibility rather than for any financial reward" (2).

Australian Bureau of Statistics (2007) reported that younger volunteers are the major component of the volunteer population around the world. For example, in Australia $24 \%$ of the population was engaged in some forms of volunteer activities in 1995. This percentage has 
increased to reach $34 \%$ in 2007 . However, the volunteer rate for the age group (18-24 years) has increased from $17 \%$ at 1995 to $30 \%$ in $2006^{(3)}$. On the other hand, other studies revealed that young people are more likely to participate in volunteer work than older one and people who volunteer while in school are more likely to volunteer later in their lives (1). However, Finlay and Murray (2005) reported that there is accepted strong relation between level of education and volunteering among young volunteers. Since, he suggests that the volunteering rate will be higher among students than among general population within the same age group ${ }^{(4)}$.

In addition, Australian Bureau of Statistics (2007) found that volunteering rate among students aged 18-24 years was $43.4 \%$ compared to $20.1 \%$ of those at the same age group and were not students ${ }^{(3)}$.

Many of the studies supported that most of people who volunteer in different activities are affected by many different motives. Hyde and Knowles (2013) showed that these motives like to engage in volunteer activities in order to help others, some people involve in volunteering activities because of their families and friends motivation ${ }^{(5)}$. Similar motives were reported by Bendania, Al Dini, Garris (2012) who conclude that family and friends involvement in volunteering predict respondent's volunteering ${ }^{(6)}$. However other people participate because of the positive outcome that they may gain such as money or appreciation certificates, in addition to satisfying their own moral, ethical and religious needs ${ }^{(6)}$.

However, literatures revealed that young people volunteer for different motives and benefits than older adult. Eley (2003) reported that gaining work related experiences, skills and qualification are major motives for young volunteers because it can help them in education and career $^{(7)}$. While Bendania (2012) showed that the main motives for volunteering in their study were values, understanding, enhancement and social motives ${ }^{(6)}$.
The volunteer work has crucial role in providing and functioning the communities' social services and the nation as whole in addition to its practical benefits for the volunteers themselves. Both communities and individuals benefits from volunteering through the development of social network and social cohesion ${ }^{(3)}$. However, in every society young people are known as today's thinkers, problem-solvers and advocates, particularly that they represent the largest group in most of societies. Therefore, they enhance the power of volunteerism ${ }^{(8)}$.

Literature reveals variety of benefits for participation in voluntary activities. Musick and Wilson (2008) reported that there are multiple benefits of volunteering for young people including enhancement of academic development, improving personal skills and sense of civic responsibilities, in addition to the benefits associated with career choice and employability after $\operatorname{graduation}^{(9)}$.

On the other hand, Holds Worth (2010) found that helping people in the communities to learn new skills and building future career are the major reasons for volunteering among young volunteers ${ }^{(10)}$. However, Romos (2003) revealed that volunteerism among young people is strongly related to the community, acquiring new skills, participation with friends, meeting the higher education requirements and career building ${ }^{(11)}$.

However, Virola, Ilarina, Reyes and Buenaventura (2010) conclude that a significant benefit for volunteering involvement is the development of a strong sense of mutual trust and cohesion ${ }^{(12)}$. In addition, repetitive involvement in volunteer work showed to be linked with enhancing the learning skills, such as better academic performance and strengthens critical thinking practice ${ }^{(12)}$. Astin and Sax (1998) as well as Llenares and Deocaris (2015) noted positive outcomes of volunteerism in personal growth, selfknowledge, self-esteem and personal efficacy $^{(13,14)}$. 
Regarding the importance of these motives and benefits for the young volunteers, studies revealed that having more experience in volunteerism may lead to changing the importance of these motives to young volunteers. Another factor which may play a role in ordering the importance of different motives is the age of the volunteers, since Greenslade and White (2005) found that career related motives have been shown to be more important for the younger than older volunteers while social motives become more important for older volunteers ${ }^{(15)}$. On the other hand, Hyde and Knowles (2013) noted that people who are not engaging in voluntary activities have different barriers such as limitation of time because they are involved in working or studying, lack of awareness and knowledge and some people has no interest due to focusing on own wellbeing rather than others. Further, some people have priorities as they prioritize their career or have family responsibilities ${ }^{(5)}$. However, Evans and Saxton (2005) reported that students face a lot of barriers for volunteering such as rising of educational cost, the need for more paid work ${ }^{(16)}$.

Volunteering meaning is much more than the action to complete a task. It is about the links that bring people together, and that strengthen society. The human desire to increase in helping the needy has been a feature of all human societies through history, irrespective of religion, culture, and civilization. As in Saudi Arabia civilization and religion for instances, volunteering is confirm as a central value of the Islamic culture and its traditions throughout generations as a section of the moral values of the Muslim societies ${ }^{(17)}$.

In Saudi Arabia, there are roughly fifteen international charitable organizations functioning in Saudi Arabia, in addition to numerous national organizations, but actually, the concept of volunteering is not too well understood locally and is bound by red tape and bureaucracy ${ }^{(18)}$. Recently the government acts hardly to encourage the young population to participate in voluntary activities. In this respect at 2003 in Jeddah, The international conference on youth volunteering and dialogue was held with the attendance of more than 200 young volunteers from 33 different countries with the delegates of UNESCO, the Saudi Arabia Ministry of education and King Abdulaziz center of national Dialogue. The conference provided young volunteers, experts and practitioners with the opportunity to discuss display and evaluate best practices in the field of volunteering ${ }^{(8)}$.

It is worth mentioning that few studies among the reviewed literatures have examined volunteering work in Saudi Arabia, particularly among young volunteers. Nursing students provide a unique sample of the young Saudis to examine in the volunteering context given, since they have often more flexibility in their time schedule to offer voluntary activities. In addition they have the opportunity to encourage other young people to undertake volunteering given their often students network. Therefore, the researchers decided upon conducting this study to investigate the motives and barriers that affect the participation of nursing students in voluntary activities. Since, the more we understand the motivations and barriers underlying the volunteering in this age group, the more strategies will be obtain that can be used to encourage young people to engage in volunteering activities.

\section{Aim of the Study}

This study aimed to investigate the motives and barriers that affect the participation of nursing students in voluntary activities at College of Nursing Jeddah.

\section{Research Questions:}

1. What are the motives that enhance the nursing students' participation in voluntary activities?

2. What are the barriers that inhibit the nursing students' participation in voluntary activities? 
3. What is the relationship between the highly ranked motive and barrier and participant's demographic characteristics?

\section{Materials and Method}

\section{Materials}

Design: A quantitative cross - sectional design was utilized to conduct the study. Data collected once and multiple outcomes were studied.

Setting: The study was conducted in the College of Nursing and the College of Basic Sciences affiliated to King Saud bin AbdulAziz University for Health Sciences in the western region, Jeddah, KSA.

Subjects: $\quad$ Non-probability, convenient sampling techniques was used to involve students in this study. This method is recommended by the researchers for using readily accessible subjects who volunteer to participate in the study ${ }^{(19)}$.

All nursing students who were registered in students information system (SIS) were invited to participate in the current study, either they were in Stream I program which catering for high school graduates and extending over a period of 4 years or students who were in Stream II program which catering for University graduates who wish to join Nursing as a second career. The student was eligible for participation if she is a nursing student, registered during the semester when data was collected and willing to participate.

Those who agreed to voluntary participate were accounted a total of 199 students out of approximately 350 students as a total population, who represented all 8 academic levels.

\section{Tool:}

Tool I: Socio-demographic and Voluntary Experiences Structured Interview Schedule

The researchers developed the study tool after reviewing of many literatures ${ }^{(5,14,20,21,22)}$. The tool consists of four parts:
Part 1: Including student's socio demographic data such as age, marital status, birth order, number of children if married, place of residence, level of education and stream.

Part 2: Including socio demographic data of student's family such as age, level of education, occupation of parents, family income and number of family members.

Part 3: Including data about student's volunteering activities such students own definition of volunteer work, student's participation in volunteer activities, frequency of participation, type of volunteer activities, motives and barriers experienced by the students, regularity in participation in voluntary activities, ways of participation, benefits of participation and willing to continue participation in voluntary activities.

Part 4: Including data about barriers that prevent nursing students to participate in voluntary activities (only for students who never participate in any volunteer activities).

\section{Method}

- Approval letter from the university administration was obtained to collect data.

- Validity of the tool was tested by a group of 5 experts in the field and their opinions were taken into consideration.

- The reliability of the tool was tested using Cronbach's alpha which value was (.938).

- A pilot study was carried out on 10 of nursing students who were not included in the study in order to assure the clarity, applicability and comprehension of the tool. Accordingly, the necessary modifications were done.

- The study subjects were approached after obtaining the list of academic levels and courses registration obtained from the department of student's admission and registration. Arrangement was made with courses' 
coordinators for distribution of the study instrument. Students in the preprofessional years were approached in the college of basic sciences after arrangement with student's affairs and course coordinators; however, students in the professional nursing program were approached at college of nursing.

- Once the students were recruited and agreed to participate in the study and signed the consent form, they were asked to fill the study questionnaires. The researchers distributed the research instruments to the students and gave them the essential instructions to fill it.

- After completing the questionnaires the researchers collected the questionnaire from the students, and then data was coded and prepared for analysis.

\section{Ethical considerations:}

Permission to conduct the study was obtained from the Institutional Review Board (IRB) office and Research Ethics Committee of the College. The participants were informed about the purpose of the research and the main instructions were given by the researchers. The informed consent was secured from each participant with complete assurance of their right to withdraw from the study at any time. In addition, the anonymity was assured where a code number was used to label each questionnaire. After data collection the questionnaires were handled by the researchers only and kept in secured place.

\section{Statistical Analysis}

Statistical Package for the Social Sciences (SPSS) vision 20 was used to analyze research data. Descriptive as well as inferential statistics were carried out. Descriptive statistics was included means, percentages and frequencies. Inferential statistics included chi-square to test the relationship between the main outcomes (motives \& barriers) and the study subjects' characteristics especially that the variables were categorical.

\section{Results}

Table (1) shows the socio demographic characteristics of the studied students and their families. The table shows that most of volunteer students $(89.4 \%)$ were single.

Regarding the number of children of the married students, $27.3 \%$ of volunteer students as compared to $50 \%$ of nonvolunteer students had one child while $18.1 \%$ of volunteer students as compared to $7.1 \%$ of non-volunteer students had two children. However, those who had no children constitute $54.6 \%$ of volunteer students as compared to $35.6 \%$ of nonvolunteer students.

Concerning the students' birth order, the table reveals that more than one fourth $(26.9 \%)$ of the volunteer students as compared to $20 \%$ of non-volunteer students were the 1 st child in their families while $20.2 \%$ of the volunteer students as compared to $16.8 \%$ of non-volunteer students ranked the 2nd child. However, those who ranked the 3 rd child were $24 \%$ of volunteer students and $21.1 \%$ of nonvolunteer students.

As regard to students' place of residence, the result reveals that more than half of the both groups (68.3\% and 57.9\%) of volunteer and non-volunteer respectively were living far from the college.

Concerning the academic stream of the students, the result shows that, most of volunteer students $(86.5 \%)$ were in stream 1 while $13.5 \%$ of them were in stream II. On the other hand, the junior students from both streams I and stream II constitute more than one thirds $(34.6 \%)$ of volunteer students as compared to $54.7 \%$ of nonvolunteer students. However, senior students from both streams I and stream II constitute $65.4 \%$ of volunteer students as compared to $45.3 \%$ of non-volunteer students with a significant difference $(\mathrm{P}=.003)$ in favor of senior volunteer students.

In relation to fathers' age of the students, the study reveals that the father age of $15.4 \%$ of volunteer students as 
compared to $23.2 \%$ of non-volunteer students were 40-49 years while almost half $(49 \%)$ of fathers of volunteer students as compared to more than half $(52.6 \%)$ of fathers of non-volunteer students aged 5059 years.

Concerning fathers' level of education, the study reported that, small percentage $(5.8 \%)$ of fathers of volunteer students as compared to $21.1 \%$ of fathers of nonvolunteer students were illiterate while $20.2 \%$ of fathers of volunteer students as compared to $13.7 \%$ of fathers of nonvolunteer students completed their secondary school education. However, those who had bachelor degree constitute $24 \%$ of fathers of volunteer students as compared to only $15.8 \%$ of fathers of nonvolunteer students. Significant relation was observed in favor of volunteer students whose father are holding bachelor degree $(\mathrm{P}=0.000)$.

Regarding fathers' occupation, the table shows that less than one half $(41.4 \%)$ and $(34.7 \%)$ of fathers of both volunteer and non-volunteers students respectively were working while those who retired constitutes $51.9 \%$ of fathers of volunteer students and $48.5 \%$ of fathers of non-volunteer students.

In relation to Mothers' age, the study shows that nearly equal percentage $61.6 \%$ and $62.3 \%$ of volunteer \&non volunteer students' mothers respectively aged 40-49 years.

As regard to level of education of students' mothers, the study reveals that minor percentage $(2.9 \%)$ of mothers of volunteer students as compared to $12.6 \%$ mothers of non-volunteer students were illiterate while $19.3 \%$ of mothers of volunteer students as compared to $15.8 \%$ of mothers of non-volunteer students completed their secondary school education. Those who had bachelor degree constitute $36.5 \%$ of mothers of volunteer students as compared to $9.5 \%$ of mothers of non-volunteer students with a significant difference $(\mathrm{P}=.000)$ in favor of volunteer students whose mothers are holding bachelor degree.
Regarding Mothers' occupation, the study reveals that less than half $(46.2 \%)$ of mothers of volunteer students were working as compared to $21.1 \%$ of mothers of nonvolunteer students were working while the rest of them were housewives.A significant relation was observed $(\mathrm{P}=.000)$ in a favor of volunteer students whose mothers are working.

Concerning the family income, the result shows that more than two thirds $(68.3 \%)$ of the volunteer students as compared to $70.5 \%$ of non-volunteer students had sufficient family income. However, $6.7 \%$ of volunteer student as compared to $13.7 \%$ of non-volunteer students had insufficient family income.

Table (2) shows the voluntary experience among volunteer students. About one half $(49 \%)$ of the students recently participate in voluntary activities while $35.6 \%$ participated one year ago and $15.4 \%$ participated more than one year ago.

The study also revealed that more than one half $(62.5 \%)$ of the voluntary activities were conducted outside university field while $28.8 \%$ of these activities were conducted inside university however, small percentage $(8.7 \%)$ were conducted in charity associations.

Concerning the regularity of participation, the study revealed that more than half $(54.8 \%)$ of volunteer students were participated in voluntary activities in regular basis while the rest of them were participated in irregular basis (occasional).

Regarding time of participation for regular basis volunteers, the table shows that more than one third of them $(36.8 \%)$ were volunteer during vacations while $15.8 \%$ were volunteer during academic semesters and $47.4 \%$ of them were participated in voluntary activities during both vacations and academic semesters.

In relation to the average time spent in these activities. The table shows that more than one third $(36.8 \%)$ of the regular basis 
volunteer students reported no specific time while $24.6 \%$ of them spent more than three hours per week. However, those who spent from two to three hours per week constitute $21.1 \%$ of them.

Regarding frequency of participation of students who participate on irregular basis, the result reveals that about one-fourth (23.4\%) of them participated only one time while $42.6 \%$ of them participated two times. However, those who participated three times or more constitute $34 \%$ of them.

As regard to types of students' voluntary activities, the table shows that health related activities were the most common activities among the volunteer students as reported by $69.2 \%$ of them, followed by religious and entertainment related activities in equalized percentage $(16,3 \%), 9.6 \%$ in environmental activities and $5.7 \%$ in sports related activities.

Concerning ways of students' participation in voluntary activities, the results shows that $47.1 \%$ of them participated through social media while $37.5 \%$ of them participated through their friends. However, more than one tenth $(15.4 \%)$ were participated through academic activities.

In relation to the barriers faced the volunteer students while participation, the study reveals that academic problem was the 1 st barrier as reported by $21.2 \%$ of the volunteers followed by economic and social problems as reported by $19.2 \% \quad 17.3 \%$ respectively.

Regarding willingness of volunteer students to continue participation, most of the students $(82.7 \%)$ were willing to continue their participation while the rest of them were not willing.

Figure (1) reflects the reported correct complete definition of voluntary activities. It reveals that more than one half $(55 \%)$ of volunteer students as compared to $45 \%$ of non-volunteer students stated complete correct definition of voluntary activities.
Figure (2) presents the highest motives that enhance the nursing students 'participation in voluntary activities. $72.2 \%$ of the volunteer students mentioned many motives. The most five reported motives were ranked as follow: Passion to help others was reported by more than fourth of the students $(26.6 \%)$, while students desire to improve their personal and communication skills was the second motive as reported by $15.1 \%$ of them. However, third and fourth motives were available free time and desire to make new friends as reported by $9.5 \%$ and $9 \%$ respectively. The fifth and last motive was family encouragement as reported by less than one tenth $(8 \%)$ of the students.

Figure (3) presents the highest barriers that inhibit the nursing students' participation in voluntary activities. $64.3 \%$ of non-volunteer students reported different barriers. The most five reported barriers were ranked as follow: First barrier that reported by $21.1 \%$ of non-volunteer student was unavailability of time, while lack of awareness about ways of participation was the second barrier as reported by $13.1 \%$ of them. However, about one tenth $(11.1 \%)$ of them reported economic barriers and $9.5 \%$ reported either the objection of family or lack of personal and social skills as barriers for participation.

Figure (4) presents the perceived benefits of participation in voluntary activities among both senior and junior volunteer students. Improving the communication skills was perceived as $1^{\text {st }}$ benefit as reported by $25.2 \%$ of seniors students as compared to less than one fifth $(19.3 \%)$ of junior students. However, adding valuable experience to their curriculum vita $(\mathrm{CV})$ was the 2 nd reported benefit as reported by $18 \%$ of senior students as compared to only $2.3 \%$ of junior students. On the other hand, $13.6 \%$ of the junior students as compared to less than one tenth $(7.2 \%)$ of senior students reported that feeling proud in solving people problem was the perceived benefit for participation in voluntary activities, while $9 \%$ of senior 
students as compared to only $4.5 \%$ of junior students mentioned that feeling of high selfesteem was the perceived benefit. Minor percentage of both senior students and junior students $1.8 \%, 1.1 \%$ respectively mentioned that acquiring large number of friends was the perceived benefit.

Table (3) and (4) answering the research question number three; what is the relationship between the highly ranked motive and barrier and participant's demographic characteristics? As following:

Table (3) shows the relationships between the highest priority motive and participants`s demographic characteristics. Majority (96.2\%) of volunteering students who select the "passion about charity and volunteering work to help other" as the highest priority motive were single while the rest of them were married with a significant relation between the groups $(\mathrm{P}=0$ $.024)$. However, $94.3 \%$ of them were in stream 1 while the rest of them were in stream II with a significant relation between the groups $(\mathrm{P}=0.013)$. The table also revealed that more than half $(58.5 \%)$ of them were senior students groups. On the other hand, significant relation was observed between father's level of education and choosing the highest priority motive $(\mathrm{P}=0$.006). Since more than one fourth $(28.3 \%)$ of the fathers had a bachelor's degree and $24.5 \%$ of them had completed their high school education.

Table (4) reveals the relationship between the highest priority barrier and participants' demographic characteristics. The study shows that most $(85.7 \%)$ of the students who select ((no time to participate)) as the highest priority barrier were single while the rest of them were married with a no significant relation. However, $76.2 \%$ of them were in stream 1 while the rest of them were in stream II. The table also revealed that about half $(54.7 \%)$ of them were junior students. On the other hand, significant relation was observed between father's occupation and choosing the highest priority barrier since $50 \%$ of the students fathers were retired
$(\mathrm{P}=0.012)$. Other significant relation was observed between family income and the highest priority barrier since $69.04 \%$ of the students had sufficient family income while $19.04 \%$ had insufficient family income $(\mathrm{P}=$ $0.044)$.

\section{Discussion}

The study aimed to investigate the motives and barriers that affect the participation of nursing students in voluntary activities. In addition, the relationship between the highly ranked motive and barrier and participant's demographic characteristics.

In relation to the definition of volunteerism the study revealed that more than one half $(55 \%)$ of volunteer students as compared by $45 \%$ of non-volunteer were selected the most appropriate concept, which was reported by Wilson (2000) as "any activity, formal or informal, which is conducted by choice in an unpaid manner to benefit another person, group, or organization", (1).

The current study revealed that more than half of the total sample (52.3\%) participated in voluntary activities. This result comes in accordance with the study conducted in Saudi Arabia by Bendania (2012) who reported that $65.1 \%$ of the university population was volunteers ${ }^{(6)}$. These results can be explained as the nursing students has a big chance to participate in different voluntary activities through different channels such as, Student club, friends motivation, voluntary activities of the academic courses and social media. On the other hand, less participation percentage ( $43 \%$ ) was reported by Hyde, k., and Knowles $(2013)^{(5)}$.

In contrast to Hyde, k., and Knowles`s study (2013) reported that almost two thirds of the students' sample was volunteering in irregular basis ${ }^{(5)}$. The current study revealed that more than half of the nursing students participated in voluntary activities on regular basis that may reflect the strong motives that the students had for participation. 
Regarding to the types of the volunteering activities, the present study revealed that most of the volunteer students were engaged in health related voluntary activities, which my give an explanation of the desire to improve their skills and knowledge in the health related filed. The second type of voluntary activities as reported by the students was religious related activities, which might be well explained by the religious nature of the society. These results are similar to McCabe (2007), study who mentioned that the university students in different fields reported assisting elderly and religious activities as the most common types in voluntary activities ${ }^{(20)}$. However, the presence of the differences in each type of voluntary activities may be related to the differences in academic's specialty in addition to the different culture of the society $^{(20)}$.

The current study revealed that approximately two thirds of the study subjects who volunteered were seniors $(65.4 \%)$. The results reflect that the senior students have more skills and knowledge that enable them to participate in voluntary activities. In addition, they have a strong motive to develop their future carrier that enhances their participation. In this respect, the current results support these explanations since adding experience to C.V for career development and having a good chance of job placements were the second reported benefits from the volunteering senior students. These results come in line with the study of Kelly (2014) who reported that the last year undergraduate students were more motivated as the voluntary activities increase the opportunity for the students to enhance their future career ${ }^{(21)}$.

Regarding to the marital status of the volunteer students, the current study shows that the single students were more participated than married students. This may be explained by, the fact that the single students have more free time and less familial responsibilities that allow them to participate in voluntary activities.

Based on the literature review, different studies reported many motives that enhance the students 'participation in voluntary activities ${ }^{(21,22,23,24,25)}$. The current study revealed that the most common motives that reported by the volunteers by priority were passion to help others, improving skills, making new friends, family encouragement and free time. These results can be explained by the fact that nursing is a profession of giving and elevating suffering, and nursing students were socialized to possess moral, ethical obligation to provide help and support to vulnerable population and society. This result come in line with the study conducted among university students by Smith and Holmes (2010) who mentioned that the motives that affect students' participation were important to help others, improving the C.V and to make new friends ${ }^{(22)}$. On the other hand, different motivational factors were reported by Kelly, N (2014) who reveals that the last year undergraduate students were motivated by career opportunities, making a positive impact on society and the opportunity to learn and develop new skills and qualities ${ }^{(21)}$. These differences may be related to different study groups, nature of academic study and different cultures.

Meanwhile, most of the volunteer students perceived different gained benefits for participation in voluntary activities. The current study shows that the benefits gained by the students who participated in voluntary activities in priority were improving communication skills, add experiences to the $\mathrm{C} . \mathrm{V}$, proud in solving society problems, high self-steam and gained large number of relationships. However, Kelly (2014) found that the final year undergraduate students had choose the benefits in order as; increased satisfaction and happiness, impact on college course content and development of valuable contacts $^{(21)}$. However, changing the priority of the benefits for the participants may be 
related to the differences in the study subjects and nature of their study in addition to cultural issues.

It is worth to note that improving communication skills and adding experience to C.V were more reported benefits by senior volunteer students than junior students; these results can be explained by the fact that senior students are preparing themselves to build new carriers and having good chances of specialty and job. While feeling proud and honor in solving society problems was more perceived benefit by the junior, this can be a reflection to their energy, excitement, power and strong desire to have selfsatisfaction.

In contrast to the students who volunteer, the students who didn't participate in voluntary activities had barriers that inhibit their participation. The current study shows the barriers by priority as reported by the students including, time limitation, unaware about the way of participation, economic cost of the activities, objection of the family and limited personal and social skills. These reported barriers can be explained by the fact that any university students in general and specially those who have both theoretical and clinical courses as nursing students usually overwhelmed by variety of requirements and assignments and usually have limited free time. In addition, the objection of the family as reported barrier reflect Saudi culture issue relating to volunteering specially among female and ensuring that the concept of volunteering is not well understood among Saudi population $^{(17)}$.

However, the economic barrier was one of the barriers that reported by the students that come in line with the result of the present study which revealed that nonvolunteer students had insufficient income than volunteering participants. This result comes in line with key barriers identified in the Kelly (2014) who reported that time management, age limitations and lack of experience and financial constraints were the common reported barriers ${ }^{(21)}$.

\section{Limitations of the Study}

The generalizability of the results is limited due to the use of a non-probability, convenience sample and to collecting data from one university.

More time and effort were needed in excluding and approaching the nursing students at the College of Basic Sciences.

\section{Conclusion}

The study concluded that participation of nursing students in voluntary activities is governed by variety of motives such as passion to help others, improving skills, making new friends, family encouragement and free time. However, a lot of barriers were reported such as time limitation, lack of awareness about the way of participation, economic cost of the activities, objection of the family and limited personal and social skills. Moreover the study conclude that more than half of the nursing students have participated in voluntary activities on a regular basis and the participation in health related activities was the common type of voluntary activities followed by religious activities which actually reflect both cultural and academic nature of the setting. In summary, it could be concluded that senior students are more active than junior in participating in voluntary activities, specifically, those senior whose parents are educated at a bachelor level.

In addition, it can be concluded that the marital status of the students play a significant role in their participation since single students were more participating than married one. Also, it is concluded that the more the motivations and barriers underlying the volunteering among nursing students are understood, the more informed the strategies that can be used to encourage them to engage in volunteering. 


\section{Recommendations}

Based on the results of the study the following recommendations are presented:

1. Increase students awareness about the benefits of volunteering activities, ways of participation and different forms of volunteering activities must be taken into considerations to improve the society awareness as whole.

2. Further researches such as qualitative studies need to be conducted in order to get insight into the motives and barriers of participation.

3. Collaborated efforts from university authority, students clubs, and faculties' as well nongovernmental organization should be encouraged to overcome the identified barriers and to provide complete supports and motivation for the participants.

4. Conducting a research in more than one university with a large sample to ensure the generalizability of the study. 
Table (1): Socio demographic characteristics of the students and their families among volunteering and non volunteering participants

\begin{tabular}{|c|c|c|c|c|c|}
\hline \multirow[t]{2}{*}{ Variables } & \multicolumn{2}{|c|}{$\begin{array}{l}\text { Volunteering } \\
\text { participants } \\
=104\end{array}$} & \multicolumn{2}{|c|}{$\begin{array}{c}\text { Non volunteering } \\
\text { participants } \\
=95\end{array}$} & \multirow[t]{2}{*}{$\begin{array}{l}\text { P value } \\
\text { of } \chi^{2}\end{array}$} \\
\hline & Frequency & Percentage & Frequency & Percentage & \\
\hline $\begin{array}{l}\text { Marital status } \\
\text { Single } \\
\text { Married }\end{array}$ & $\begin{array}{l}93 \\
11\end{array}$ & $\begin{array}{l}89.4 \% \\
10.6 \%\end{array}$ & $\begin{array}{l}81 \\
14\end{array}$ & $\begin{array}{l}85.3 \% \\
14.7 \%\end{array}$ & 0.251 \\
\hline $\begin{array}{l}\text { Number of children if married } \\
\text { One child } \\
\text { Two children } \\
\text { Three children } \\
\text { None }\end{array}$ & $\begin{array}{l}3 \\
2 \\
0 \\
6\end{array}$ & $\begin{array}{c}27.3 \% \\
18.1 \% \\
0.0 \% \\
54.6 \% \\
\end{array}$ & $\begin{array}{l}7 \\
1 \\
1 \\
5\end{array}$ & $\begin{array}{c}50 \% \\
7.1 \% \\
7.1 \% \\
35.7 \% \\
\end{array}$ & 0.35 \\
\hline $\begin{array}{l}\text { Birth order } \\
\text { First } \\
\text { Second } \\
\text { Third } \\
\text { Fourth } \\
\text { Fifth } \\
\text { Sixth and more }\end{array}$ & $\begin{array}{l}28 \\
21 \\
25 \\
11 \\
10 \\
9\end{array}$ & $\begin{array}{c}26.9 \% \\
20.2 \% \\
24 \% \\
10.6 \% \\
9.6 \% \\
8.7 \% \\
\end{array}$ & $\begin{array}{c}19 \\
16 \\
20 \\
14 \\
9 \\
17\end{array}$ & $\begin{array}{c}20 \% \\
16.8 \% \\
21.1 \% \\
14.7 \% \\
9.5 \% \\
17.9 \% \\
\end{array}$ & 0.310 \\
\hline $\begin{array}{l}\text { Place of residence } \\
\text { Near from the university location } \\
\text { Far from the university location }\end{array}$ & $\begin{array}{l}33 \\
71 \\
\end{array}$ & $\begin{array}{l}31.7 \% \\
68.3 \% \\
\end{array}$ & $\begin{array}{l}40 \\
55 \\
\end{array}$ & $\begin{array}{l}42.1 \% \\
57.9 \% \\
\end{array}$ & 0.085 \\
\hline $\begin{array}{l}\text { Juniors } \\
\text { Seniors }\end{array}$ & $\begin{array}{l}36 \\
68 \\
\end{array}$ & $\begin{array}{l}34.6 \% \\
65.4 \% \\
\end{array}$ & $\begin{array}{l}52 \\
43 \\
\end{array}$ & $\begin{array}{l}54.7 \% \\
45.3 \% \\
\end{array}$ & $0.003 *$ \\
\hline $\begin{array}{l}\text { Stream } \\
\text { Stream } 1 \\
\text { Stream } 2 \\
\end{array}$ & $\begin{array}{l}90 \\
14 \\
\end{array}$ & $\begin{array}{l}86.5 \% \\
13.5 \% \\
\end{array}$ & $\begin{array}{l}76 \\
19 \\
\end{array}$ & $\begin{array}{l}80 \% \\
20 \% \\
\end{array}$ & 0.147 \\
\hline $\begin{array}{l}\text { Father's age } \\
40-49 \text { years } \\
50-59 \text { years } \\
60 \text { years and more } \\
\end{array}$ & $\begin{array}{l}16 \\
51 \\
37\end{array}$ & $\begin{array}{c}\frac{15.4 \%}{49 \%} \\
35.6 \%\end{array}$ & $\begin{array}{l}22 \\
50 \\
23\end{array}$ & $\begin{array}{l}23.2 \% \\
52.6 \% \\
24.2 \%\end{array}$ & 0.148 \\
\hline $\begin{array}{l}\text { Father's level of education } \\
\text { Illiterate (can't read \&write) } \\
\text { Read and Write } \\
\text { Complete elementary school } \\
\text { Complete Middle school } \\
\text { Complete High school } \\
\text { Bachelor's degree } \\
\text { Post graduate degree } \\
\end{array}$ & $\begin{array}{c}6 \\
3 \\
19 \\
21 \\
23 \\
25 \\
7 \\
\end{array}$ & $\begin{array}{c}5.8 \% \\
2.9 \% \\
18.3 \% \\
20.2 \% \\
22.1 \% \\
24.0 \% \\
6.7 \% \\
\end{array}$ & $\begin{array}{c}20 \\
13 \\
12 \\
13 \\
22 \\
15 \\
0 \\
\end{array}$ & $\begin{array}{c}21.1 \% \\
13.7 \% \\
12.6 \% \\
13.7 \% \\
23.1 \% \\
15.8 \% \\
0.0 \% \\
\end{array}$ & $0.000 *$ \\
\hline $\begin{array}{l}\text { Father's occupation } \\
\text { Working } \\
\text { Not working } \\
\text { Retired }\end{array}$ & $\begin{array}{c}43 \\
7 \\
54 \\
\end{array}$ & $\begin{array}{c}41.4 \% \\
6.7 \% \\
51.9 \% \\
\end{array}$ & $\begin{array}{l}33 \\
16 \\
46 \\
\end{array}$ & $\begin{array}{l}34.7 \% \\
16.8 \% \\
48.5 \% \\
\end{array}$ & 0.079 \\
\hline $\begin{array}{l}\text { Mother's age } \\
40-49 \text { years } \\
50-59 \text { years } \\
60 \text { year and more } \\
\end{array}$ & $\begin{array}{c}64 \\
38 \\
2 \\
\end{array}$ & $\begin{array}{c}61.6 \% \\
36.5 \% \\
1.9 \% \\
\end{array}$ & $\begin{array}{c}60 \\
28 \\
7 \\
\end{array}$ & $\begin{array}{c}62.3 \% \\
33.2 \% \\
4.5 \% \\
\end{array}$ & 0.134 \\
\hline
\end{tabular}

*Significant at $P=<0.05$ 
Table (1): Cont'd

\begin{tabular}{|c|c|c|c|c|c|}
\hline \multirow[t]{2}{*}{ Variables } & \multicolumn{2}{|c|}{$\begin{array}{l}\text { Volunteering } \\
\text { participants } \\
=104\end{array}$} & \multicolumn{2}{|c|}{$\begin{array}{l}\text { Non volunteering } \\
\text { participants } \\
=95\end{array}$} & \multirow[t]{2}{*}{$\begin{array}{c}\text { P value } \\
\text { of } \chi^{2}\end{array}$} \\
\hline & Frequency & Percentage & Frequency & Percentage & \\
\hline \multicolumn{6}{|l|}{ Mother's level of education } \\
\hline Illiterate & 3 & $2.9 \%$ & 12 & $12.6 \%$ & \multirow{7}{*}{$0.000^{*}$} \\
\hline Read and Write & 9 & $8.7 \%$ & 20 & $21.1 \%$ & \\
\hline Complete elementary school & 12 & $11.5 \%$ & 17 & $17.9 \%$ & \\
\hline Complete intermediate school & 20 & $19.3 \%$ & 15 & $15.8 \%$ & \\
\hline Complete High school & 15 & $14.4 \%$ & 20 & $21.1 \%$ & \\
\hline Bachelor's degree & 38 & $36.5 \%$ & 9 & $9.5 \%$ & \\
\hline Post graduate degree & 7 & $6.7 \%$ & 2 & $2 \%$ & \\
\hline \multicolumn{6}{|l|}{ Mother's occupation } \\
\hline Working & 48 & $46.2 \%$ & 20 & $21.1 \%$ & \multirow{2}{*}{$0.000 *$} \\
\hline House wife & 56 & $53.8 \%$ & 75 & $78.9 \%$ & \\
\hline \multicolumn{6}{|l|}{ Family income sufficiency } \\
\hline Sufficient & 71 & $68.3 \%$ & 67 & $70.5 \%$ & \multirow{3}{*}{0.107} \\
\hline Not sufficient & 7 & $6.7 \%$ & 13 & $13.7 \%$ & \\
\hline Sufficient and save & 26 & $25 \%$ & 15 & $15.8 \%$ & \\
\hline
\end{tabular}

*Significant at $P=<0.05$ 
Table (2): Voluntary Experiences among volunteer Students

\begin{tabular}{|c|c|c|}
\hline \multirow{2}{*}{ Variables } & \multicolumn{2}{|c|}{ Volunteering Participants $=104$} \\
\hline & Frequency & Percentage \\
\hline $\begin{array}{l}\text { Last voluntary activity Experience: } \\
\text { Recently } \\
\text { One year before } \\
\text { More than one year before }\end{array}$ & $\begin{array}{l}51 \\
37 \\
16\end{array}$ & $\begin{array}{c}49 \% \\
35.6 \% \\
15.4 \%\end{array}$ \\
\hline $\begin{array}{l}\text { Setting of last voluntary activity: } \\
\text { University } \\
\text { Outside university field } \\
\text { Charity associations' voluntary programs }\end{array}$ & $\begin{array}{c}30 \\
65 \\
9\end{array}$ & $\begin{array}{l}28.8 \% \\
62.5 \% \\
8.7 \%\end{array}$ \\
\hline $\begin{array}{l}\text { Regularity in participation: } \\
\text { Regular } \\
\text { Not regular }\end{array}$ & $\begin{array}{l}57 \\
47\end{array}$ & $\begin{array}{l}54.8 \% \\
45.2 \%\end{array}$ \\
\hline $\begin{array}{l}\text { If regular: } \mathbf{n}=\mathbf{5 7} \\
\text { Times of participation: } \\
\text { During vacation } \\
\text { During academic semester } \\
\text { Both }\end{array}$ & $\begin{array}{c}21 \\
9 \\
27\end{array}$ & $\begin{array}{l}36.8 \% \\
15.8 \% \\
47.4 \%\end{array}$ \\
\hline $\begin{array}{l}\text { Average time spent in these activities: } \\
\mathbf{n}=\mathbf{5 7} \\
\text { Less than one to two hours per week } \\
\text { Two to three hours per week } \\
\text { More than three hours per week } \\
\text { No specific time }\end{array}$ & $\begin{array}{l}10 \\
12 \\
14 \\
21\end{array}$ & $\begin{array}{l}17.5 \% \\
21.1 \% \\
24.6 \% \\
36.8 \%\end{array}$ \\
\hline $\begin{array}{l}\text { If not regular: } \mathbf{n = 4 7} \\
\text { Times of participation: } \\
\text { One time } \\
\text { Twice } \\
\text { Three times or more }\end{array}$ & $\begin{array}{l}11 \\
20 \\
16\end{array}$ & $\begin{array}{l}23.4 \% \\
42.6 \% \\
34 \%\end{array}$ \\
\hline $\begin{array}{l}\text { Forms of voluntary activities: } \\
\text { Sport related activities } \\
\text { Religious related activities } \\
\text { Health related activities } \\
\text { Environmental related activities } \\
\text { Entertainment related activates } \\
\end{array}$ & $\begin{array}{c}6 \\
17 \\
72 \\
10 \\
17 \\
\end{array}$ & $\begin{array}{c}5.7 \% \\
16.3 \% \\
69.2 \% \\
9.6 \% \\
16.3 \% \\
\end{array}$ \\
\hline $\begin{array}{l}\text { *Way of participation: } \\
\text { Through a newspaper or magazine } \\
\text { Through an academic activities } \\
\text { Through friends } \\
\text { Through social media }\end{array}$ & $\begin{array}{l}14 \\
16 \\
39 \\
49\end{array}$ & $\begin{array}{l}13.5 \% \\
15.4 \% \\
37.5 \% \\
47.1 \% \\
\end{array}$ \\
\hline $\begin{array}{l}\text { *Barriers faced the volunteer while } \\
\text { participating: } \\
\text { Economical problems } \\
\text { Social Problems } \\
\text { Academic problems }\end{array}$ & $\begin{array}{l}20 \\
18 \\
22\end{array}$ & $\begin{array}{l}19.2 \% \\
17.3 \% \\
21.2 \%\end{array}$ \\
\hline $\begin{array}{l}\text { Willingness to continue participation } \\
\text { Yes } \\
\text { No }\end{array}$ & $\begin{array}{l}86 \\
18\end{array}$ & $\begin{array}{l}82.7 \% \\
17.3 \%\end{array}$ \\
\hline
\end{tabular}

*More than one answer 


\section{Complete correct definition}

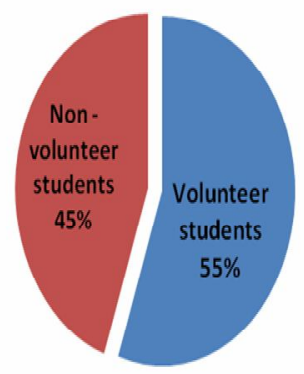

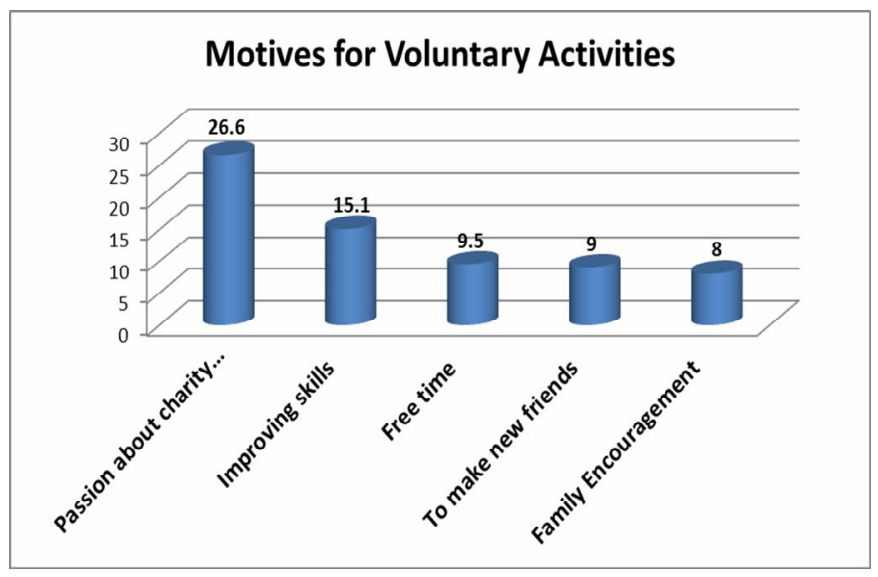

Figure (2): Distribution of volunteer students according to their reported motives
Figure (1): Distribution of the students according to complete correct definition of voluntary activity

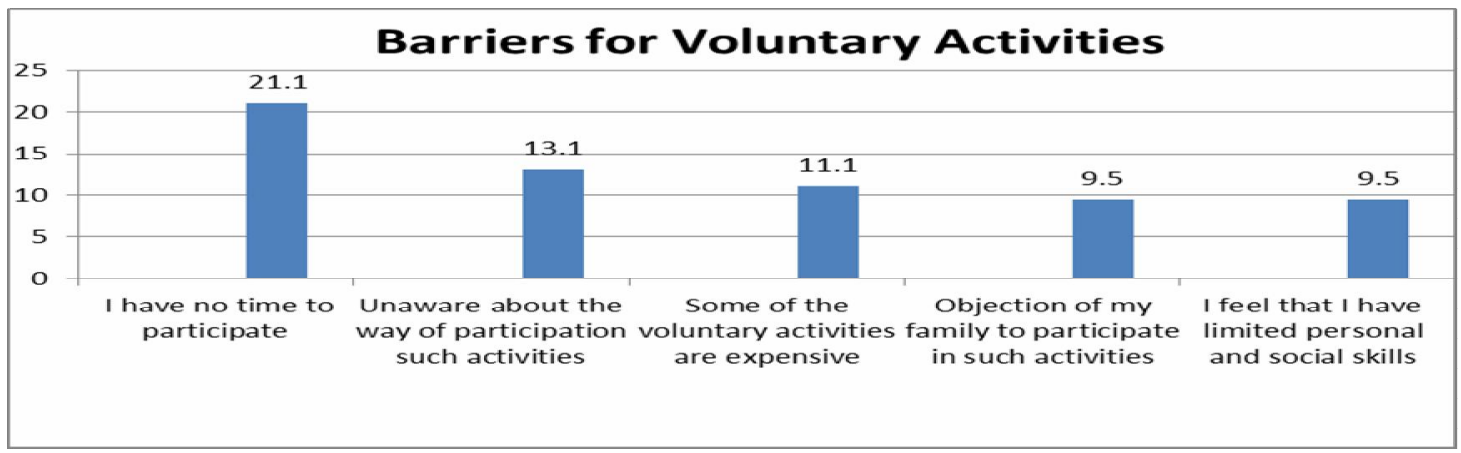

Figure (3): Barriers for voluntary activities as reported by $64.3 \%$ of the non-volunteer students

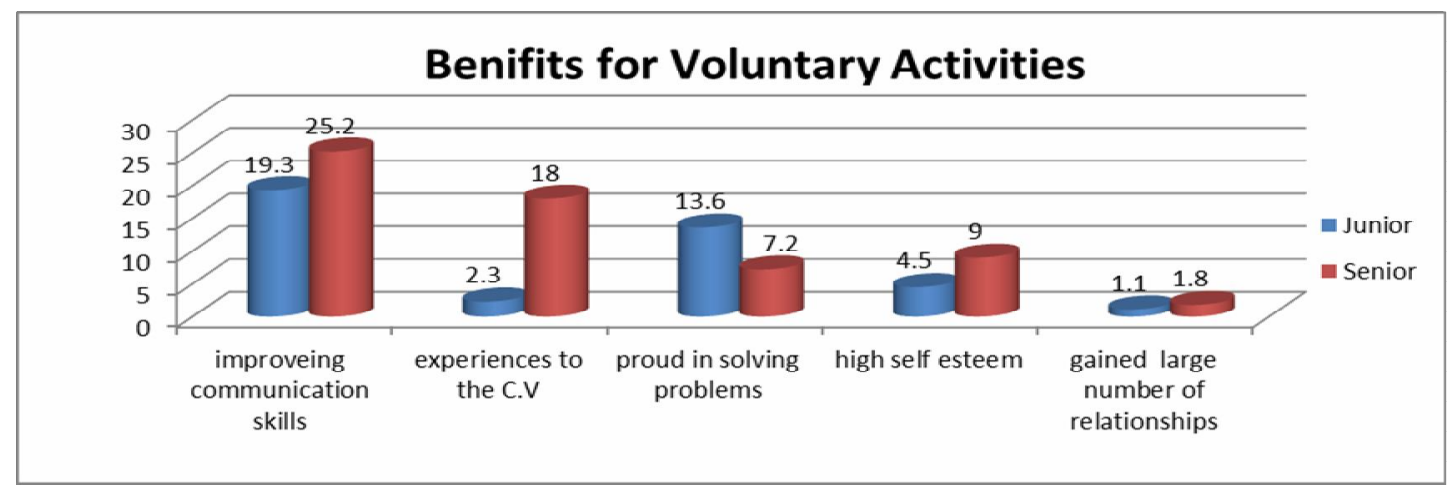

Figure (4): Distribution of the students according to reported benefits of voluntary activities 
Table (3): Relationships between the highest priority motive and participants' demographic characteristics

\begin{tabular}{|c|c|c|c|}
\hline \multirow[t]{2}{*}{ Variables } & \multicolumn{2}{|c|}{$\begin{array}{c}\text { Motive } 1 \\
\text { (Passion about charity and } \\
\text { volunteering work to help } \\
\text { others) } n=53\end{array}$} & \multirow[t]{2}{*}{$\underset{\chi^{2}}{P \text { value of }}$} \\
\hline & Frequency & Percentage & \\
\hline $\begin{array}{l}\text { Marital status } \\
\text { Single } \\
\text { Married }\end{array}$ & $\begin{array}{c}51 \\
2\end{array}$ & $\begin{array}{l}96.2 \% \\
3.8 \% \\
\end{array}$ & $0.024 *$ \\
\hline $\begin{array}{l}\text { Stream } \\
\text { Stream } 1 \\
\text { Stream } 2\end{array}$ & $\begin{array}{c}50 \\
3\end{array}$ & $\begin{array}{l}94.3 \% \\
5.7 \%\end{array}$ & $0.013^{*}$ \\
\hline $\begin{array}{l}\text { Juniors } \\
\text { Seniors }\end{array}$ & $\begin{array}{l}22 \\
31 \\
\end{array}$ & $\begin{array}{l}41.5 \% \\
58.5 \% \\
\end{array}$ & 0.643 \\
\hline $\begin{array}{l}\text { Father's level of education } \\
\text { Illiterate } \\
\text { Read and Write } \\
\text { Complete elementary school } \\
\text { Complete intermediate school } \\
\text { Complete high school } \\
\text { Bachelor's degree } \\
\text { Post graduate degree } \\
\end{array}$ & $\begin{array}{c}2 \\
1 \\
7 \\
10 \\
13 \\
15 \\
5 \\
\end{array}$ & $\begin{array}{c}3.8 \% \\
1.9 \% \\
13.2 \% \\
18.9 \% \\
24.5 \% \\
28.3 \% \\
9.4 \% \\
\end{array}$ & $0.006^{*}$ \\
\hline
\end{tabular}

*Significant at $P=<0.05$

Table (4): Relationships between the highest priority barrier and participants' demographic characteristics

\begin{tabular}{|c|c|c|c|}
\hline \multirow[t]{2}{*}{ Variables } & \multicolumn{2}{|c|}{$\begin{array}{c}\text { Barrier 1 } \\
\text { (No time to participate) } n=42\end{array}$} & \multirow[t]{2}{*}{$P$ value of $\chi^{2}$} \\
\hline & Frequency & Percentage & \\
\hline $\begin{array}{l}\text { Marital status } \\
\text { Single } \\
\text { Married }\end{array}$ & $\begin{array}{c}36 \\
6\end{array}$ & $\begin{array}{l}85.7 \% \\
14.3 \%\end{array}$ & 0.704 \\
\hline $\begin{array}{l}\text { Stream } \\
\text { Stream } 1 \\
\text { Stream } 2 \\
\end{array}$ & $\begin{array}{l}32 \\
10 \\
\end{array}$ & $\begin{array}{l}76.2 \% \\
23.8 \% \\
\end{array}$ & 0.156 \\
\hline $\begin{array}{l}\text { Juniors } \\
\text { Seniors }\end{array}$ & $\begin{array}{l}23 \\
19 \\
\end{array}$ & $\begin{array}{l}54.7 \% \\
45.3 \% \\
\end{array}$ & 0.121 \\
\hline $\begin{array}{l}\text { Father's occupation } \\
\text { Working } \\
\text { Not working } \\
\text { Retired } \\
\end{array}$ & $\begin{array}{l}11 \\
10 \\
21 \\
\end{array}$ & $\begin{array}{c}26.2 \% \\
23.8 \% \\
50 \% \\
\end{array}$ & $0.012 *$ \\
\hline $\begin{array}{l}\text { Family income sufficiency } \\
\text { Sufficient } \\
\text { Not sufficient } \\
\text { Sufficient and save } \\
\end{array}$ & $\begin{array}{c}29 \\
8 \\
5 \\
\end{array}$ & $\begin{array}{l}69.04 \% \\
19.04 \% \\
11.9 \% \\
\end{array}$ & $0.044^{*}$ \\
\hline
\end{tabular}

*Significant at $P=<0.05$ 


\section{References}

1. Wilson J. Volunteering. Annual Review of Sociology 2000; 26: 215-40.

2. Ehigiegba AE, Aivinhenyo-Uyi P, Fakunle B, Fajola A, \&Aguwa EN. Volunteerism in a Health Care Delivery System in Nigeria: A Cottage Hospital Experience. Journal of Community Med 2014; 26:108-17.

3. Australian Bureau of Statistics .Voluntary work, Australia. Canberra: Australian Bureau of Statistics 2007.

4. Finlay J \&Murray M. Possible futures: Changes, volunteering and the not-for-profit sector in Australia. Melbourne: The Smith Family 2005.

5. Hyde k \& Knowles R. What predicts Australian university students' intentions to volunteer their time for community service? Australian Journal of Psychology 2013; 65(3): 135-45.

6. Bendania A, Al Dini S \& Garris C. Motivation for Volunteering in the Kingdom of Saudi Arabia. $10^{\text {th }}$ International Conference of the International Society for Third Sector Research (ISTR), Siena, Italy 2012.

7. Eley D. Perceptions of and reflections on volunteering: The impact of community service on citizenships in students. Voluntary Action 2003; 5(3): 27-46.

8. Ouerghi G. Display and evaluate 'best practices' in the field of volunteerism, International Conference on Youth Volunteering and Dialogue 2014. Available from: http://www.unv.org/en/perspectives/doc/internati onal-conference-on-youth.html. Retrieved on: 4 February 2016.

9. Musick M A \& Wilson J. Volunteers: A social profile. Bloomington, IN: Indiana University Press. NCCPE. (n.d.). Research synthesis: Student volunteering-background, policy and context. London: National Co-coordinating Centre for Public Engagement 2008.

10. Holdsworth C\& Quinn J. Student volunteering in English higher education. Studies in Higher Education 2010; 35(1): 113-27.

11. Ramos-Mrosovsky C. The great servers. National Review 2003; 55:46-8.
12. Virola A, IIarina V, Reyes C \& Buenaventura C. Volunteerism in the Philippines: Dead or Alive? Measuring the Economic Contribution of Volunteer Work, 11th National Convention on Statistics. National Statistical Coordination Board 2010.

13. Astin W \& Sax J. How undergraduates are affected by service participation. Journal of College Students Development1998; 39:251-63

14. Llenares I \&Deocaris C. Motivations for volunteerism among Filipino college students. International Journal of Education and Research 2015; 3: (2).

15. Greenslade JH \& White KM. The prediction of above-average participation in volunteerism: A test of the theory of planned behavior and the volunteers functions inventory in older Australian adults. The Journal of Social Psychology 2005; 145: 155-72.

16. Evans E \& Saxton J. The $21^{\text {st }}$ century volunteer. London: NpfSynergy2005.

17. Youth Volunteering and Dialogue, International Conference 2013. Available at: http://www.unesco.org/new/en/bureau-ofstrategic-planning/themes/special-events/youthvolunteering-and-dialogue-conference/. Retrieved on: 28 January 2016.

18. 18. Volunteering in Saudi Arabia. The International Wanderer. Available at: http://www.theinternationalwanderer.com/volunt eering-in-saudi-arabia Retrieved on: 3 March 2016.

19. LoBiondo-Wood, G \& Haber J. Nursing Research: Methods and critical appraisal for evidence-based practice. New York: Mosby Elsevier, 2010.

20. McCabe L, White M \& Obst L. The Importance of volunteering functions to university students. Australian Journal of Volunteering 2007; 12(2): 50-8.

21. Kelly N. An exploration into the motivations, barriers, and benefits associated with volunteering among final year full-time undergraduate students. Department of Social Science 2014; 15: 1-28. 
22. Smith K, Holmes K, Haski-Leventhal D, Cnaan A, Handy F \& Brudney L. Motivations and Benefits of Student Volunteering: Comparing Regular, Occasional, and Non-Volunteers in Five Countries. Canadian Journal of Nonprofit and Social Economy Research 2010; 1(1):65-81.

23. Akintola O. What motivates people to volunteer? The case of volunteer AIDS caregivers in faithbased organizations in KwaZulu-Natal, South Africa. Health Policy and Planning 2011; 26: 53-62.
24. Geiser C, Okun A \& Grano C.Who is motivated to volunteer? A latent profile analysis linking volunteer motivation to frequency of volunteering. Psychological Test and Assessment Modeling 2014; 56 (1): 3-24.

25. Arinze S, Modebe I, Aguwa E \& Nwobodo E. Assessment of knowledge and factors that may predict willingness to volunteerism: A pilot study of community directed distributors in Anambra state. Niger J Clin Pract 2014; 18(1): 61. 